\title{
Correction: Measuring impact in the humanities: learning from accountability and economics in a contemporary history of cultural value
}

\author{
Zoe Bulaitis $^{1}$
}

Correction to: Palgrave Communications https://doi.org/10.1057/s41599-017-0002-7, published online 31 October 2017

On page 7 of the PDF under the subheading "Alternative assessment criteria in valuations of the humanities" in the second paragraph there was a quotation incorrectly attributed to Matthew Arnold (1869) which has now been corrected to attribute Oliver Bennett (2005).

The incorrect sentence was as follows:

“Therefore, an Arnoldian disposition of a 'constant and public interrogation of what is actually constituted as the best' (1869, p 479) might be a useful methodological tool through which a socially and historically informed assessment of mechanisms for attributing value might be further developed. In our present moment 'the search for cultural value would become itself the driving force of cultural policy' (1869, p 480) as Arnold argued in Culture and Anarchy".

This has now been corrected to:

"Therefore, Bennett encourages an Arnoldian disposition of a 'constant and public interrogation of what is actually constituted as the best' (2005, p 479). This might be a useful methodological tool through which a socially and historically informed assessment of mechanisms for attributing value might be further developed. In our present moment, it is worth considering how 'the search for cultural value would become itself the driving force of cultural policy' (2005, p 480) as Arnold also argued in Culture and Anarchy".

The article has been corrected online.

Published online: 27 February 2018

Open Access This article is licensed under a Creative Commons Attribution 4.0 International License, which permits use, sharing, adaptation, distribution and reproduction in any medium or format, as long as you give appropriate credit to the original author(s) and the source, provide a link to the Creative Commons license,

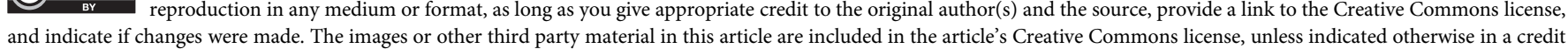
line to the material. If material is not included in the article's Creative Commons license and your intended use is not permitted by statutory regulation or exceeds the permitted use, you will need to obtain permission directly from the copyright holder. To view a copy of this license, visit http://creativecommons.org/licenses/by/4.0/.

(c) The Author(s) 2018

\footnotetext{
${ }^{1}$ School of English, University of Exeter, Exeter, UK. Correspondence and requests for materials should be addressed to Z.B. (email: zb212@exeter.ac.uk)
} 